\title{
プローブ電流密度を指標とした土壌埋設パイプラインの カソード防食設計に関する検討*
}

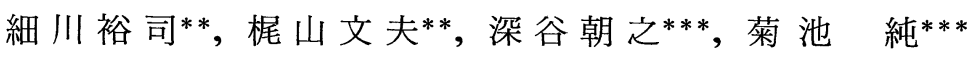

** 東京ガス株式会社 導管部

*** 日本防蝕工業株式会社

Design of CP System for Newly Constructed Pipelines with Respect to Cathodic Protection Criteria Based on DC and AC Current Densities

Measured Using Probes*

\author{
Yuji Hosokawa**, Fumio Kajiyama**, Tomoyuki Fukaya*** and Jun Kikuchi*** \\ ** Pipeline Department, Tokyo Gas Co., Ltd. \\ *** The Nippon Corrosion Engineering Co., Ltd.
}

\begin{abstract}
Recently, the risks such as AC corrosion, overprotection and corrosion inside casing pipes are increasing on cathodically protected pipelines due to the changes in burial situations, application of new construction techniques and so on. Authors have proposed new cathodic protection (CP) criteria based on DC and AC current densities measured using probes that provide an appropriate assessment of those risks together with effective measures to eliminate those risks. The design of CP systems for newly constructed pipelines, on which those risks were likely to occur, was then successfully performed based on the new $\mathrm{CP}$ criteria. In this paper, actual procedures to design $\mathrm{CP}$ systems with respect to the new $\mathrm{CP}$ criteria are demonstrated. In addition, the methodology to eliminate the risk of $\mathrm{AC}$ corrosion is presented.
\end{abstract}

Key words : pipeline, cathodic protection, AC corrosion, overprotection, casing pipe, pipe-to-soil potential, probe, coupon, DC current density, AC current density

\section{1. 緒言}

近年, 埋設パイプラインにおける敷設環境の変化, 新 工法の導入などに伴い, 交流腐食, 過防食, 鞘管内腐食 といつた新たな防食管理上のリスクが生じている。これ らのリスクの評価においては, プローブ直流電流密度お よびプローブ交流電流密度（以下，合わせてプローブ電 流密度と称する）を計測することが有効であり，著者ら は, これらのリスクの有無を判断するための基準とし て, プローブ電流密度を指標としたカソード防食管理基 準を提案した .

本報では, 著者らの提案したプローブ電流密度を指標 とするカソード防食管理基準に従って, 交流腐食, 過防 食, 鞘管内腐食といつたリスクが懸念される新設パイプ ラインのカソード防食設計を実施したので，その考え方 と内容について述べる。 また, 交流誘導電圧を低減する ための低接地措置の考え方や実施例についても併せて述 べる.

\section{2. パイプラインの概要}

新設されたパイプラインの概略を Table 1 にまとめ た。また，パイプラインルートの概略を Fig. 1 に示し た. 図中には, 後述する外部電源装置（以下，外電と称

* 第 48 回材料と環境討論会（札幌、2001）で発表

** 干 105-8527 東京都港区海岸 1-5-20（5-20, Kaigan, 1- Chome, Minato-ku, Tokyo, 105-8527 Japan)

*** $=144-8555$ 東京都大田区南蒲田1-21-12（21-12，Minamikamata, 1-Chome, Ohta-ku, Tokyo, 144-8555 Japan)
する）などの各防食設備の設置位置についても併せて示 した. 本パイプラインは, A ラインと B ラインの 2 ラ インから構成されており，これらは互いに電気的に絶縁 されている。また，Bラインの管径 $400 \mathrm{~mm}$ 抢よび 300 $\mathrm{mm}$ のラインは, 互いに電気的に導通している.

A ラインおよび B ラインのカソード防食設計を進め るにあたり，事前に建設ルートや採用される工法につい て調查した結果, Fig. 1 に示したように, 本パイプライ ンは高圧架空送電線と並行する区間が長く, また, 直流 電気鉄道との軌条横断部を多く有することが明らかにな つた.さらに，長距離推進工法が採用され，鞘管内に敷 設される区間も長いことが明らかになった。すなわち， 本パイプラインに打いては, 交流腐食, 過防食, 鞘管内 腐食といったリスクが懸念された。これらのリスクの評 価には，プローブ電流密度の計測が必要であることか ら，建設段階よりパイプ近傍にプローブを設置し（鞘管 内も含む)，これをパイプと電気的に接続した。これら プローブを用いてフィールド試験を行い, 得られたプロ ーブ電流密度の計測結果を, プローブ電流密度を指標と するカソード防食管理基準 ${ }^{1)}$ に照らし合わせて評価を行 い，本パイプラインに対するカソード防食システムの設 計を行った。

\section{3. 試 験 方 法}

\section{1 計測項目}

本報告における著者らのフィールド試験結果は, いず れも以下の方法 ${ }^{2)}$ に従って計測されたものである. パイプラインの路線上の各計測地点（以下, TB と称 する）において，パイプ, プローブおよび照合電極から 
Table 1 Specifications for the newly constructed pipelines of Line-A and Line-B.

\begin{tabular}{|c|c|c|c|c|}
\hline & $\begin{array}{c}\text { Outside diameter } \\
(\mathbf{m m})\end{array}$ & $\begin{array}{c}\text { Length } \\
(\mathbf{k m})\end{array}$ & $\begin{array}{c}\text { Grade } \\
(\text { API 5L) }\end{array}$ & Coating \\
\hline Line-A & 600 & 27.6 & X65 & Polyethylene \\
\hline \multirow{2}{*}{ Line-B } & 400 & 7.6 & X60 & Polyethylene \\
\cline { 2 - 5 } & 300 & 0.6 & X52 & Polyethylene \\
\hline
\end{tabular}
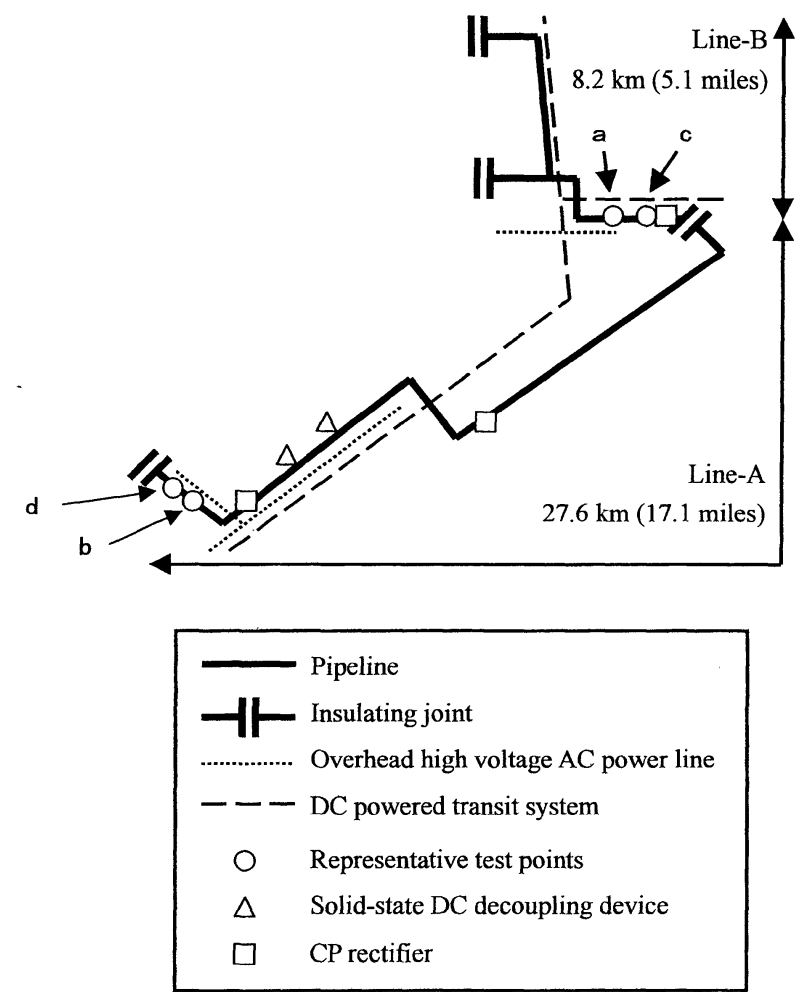

Fig. 1 Schematic of the newly constructed pipelines.

のリード線を立ち上げ，プローブ直流電流密度，プロー ブ交流電流密度, プローブ ON 電位抢よびその原波形, プローブ OFF 電位, 交流誘導電圧をそれぞれ計測し た。

\section{2 計測 方 法}

使用したプローブは，パイプラインと同一の材料から なる鋼製プローブであり，環境と接する金属面の表面積 は $1.0 \times 10^{-3} \mathrm{~m}^{2}\left(=10 \mathrm{~cm}^{2}\right)$ とした。電位計測用の照合 電極としては, 計測時にTB内あるいはその近傍に設 置した飽和硫酸銅電極を使用した。

プローブ ON 電位は，プローブとパイプを電気的に 接続している時の, プローブおよびパイプの対地電位の 計測時間中における平均值とした。 よってこの值は従来 からの管対地電位に相当するものである. プローブ $\mathrm{OFF}$ 電位は, プローブとパイプを電気的に切断してか ら $10 \mathrm{~ms} \sim 30 \mathrm{~ms}$ の, プローブの対地電位の計測時間中 に扔ける平均值とした。これは，プローブがパイプから 切断された後においても, プローブが交流誘導の影響を 受けてプローブの対地電位に $50 \mathrm{~Hz}$ の変動が見られる ケースがあるため, その 1 周期である $20 \mathrm{~ms}$ の平均值と して定義することが妥当であると判断したものである。
交流誘導電圧 $E_{\mathrm{AC}}(\mathrm{Vrms})$ は，プローブ $\mathrm{ON}$ 電位 $E_{\mathrm{ON}}$ $(\mathrm{V}$ ，飽和硫酸銅電極基準）の原波形が対称性の良い 50 $\mathrm{Hz}$ の正弦波であることを確認した上で，プローブ ON 電位の最高值 $E_{\mathrm{ON}}{ }^{\max }$ と最低值 $E_{\mathrm{ON}}{ }^{\mathrm{min}}$ から以下の式によ り計算した.

$$
E_{\mathrm{AC}}=\left\{\left(E_{\mathrm{ON}}{ }^{\max }-E_{\mathrm{ON}}{ }^{\min }\right) / 2\right\} / \sqrt{2}
$$

プローブ直流電流密度およびプローブ交流電流密度 は，プローブとパイプの間を流れる直流電流および交流 電流を計測し,これをプローブの表面積 $1.0 \times 10^{-3} \mathrm{~m}^{2}$ $\left(=10 \mathrm{~cm}^{2}\right)$ で除することにより求めた。また，プロー ブ直流電流密度は, 電流が環境側からプローブに流入す る方向を正とした。

プローブとパイプの電気的な接続時間 ( $\mathrm{ON}$ 時間) を 8.5 秒，切断時間 (OFF 時間) を 1.5 秒として，10 秒 1 サイクルによる計測を行った。計測時間は 1 分間ある いは 15 分間，また，各データのサンプリング周期は $0.1 \mathrm{~ms}$ とした。

\section{3 試 験 概 要}

以下の 3 つの試験を順に実施した。詳細については各 章で説明する。

(1) 暫定防食状況評価試験

パイプライン建設直後の暫定防食状況において，外 電の設置位置を決定することを目的として試験を行っ た。

(2) 外電設置完工試験

外電を設置した後，その効果を確認することを目的 として試験を行った。

(3) 交流誘導対策評価試験

交流誘導低減対策を実施した後，その効果を確認す ることを目的として試験を行った。

\section{4. 交流誘導低減方法決定の考え方}

本パイプラインのように，交流腐食の懸念されるパイ プラインのカソード防食設計においては，交流腐食を防 止するための交流誘導低減措置を適切に施すことが重要 である，著者らは，交流誘導低減方法を決定する際の基 本的な考え方として, Fig. 2 に示すフローのように定め た.

まず，高圧架空送電線との並行部や交流電気鉄道との 近接部など，交流誘導の影響を強く受けることが予想さ れる箇所において, パイプラインの建設時に $\mathrm{Mg}$ 電極 をパイプの近傍に埋設して，これをパイプと接続するこ とにより，分散的な接地を行うこととした． $\mathrm{Mg}$ 電極 は，5.で述べるように，建設段階の暫定的なカソード防 食を施すための犠牲陽極としてパイプに接続するもので あるが，同時に交流誘導低減のための低接地物として活 


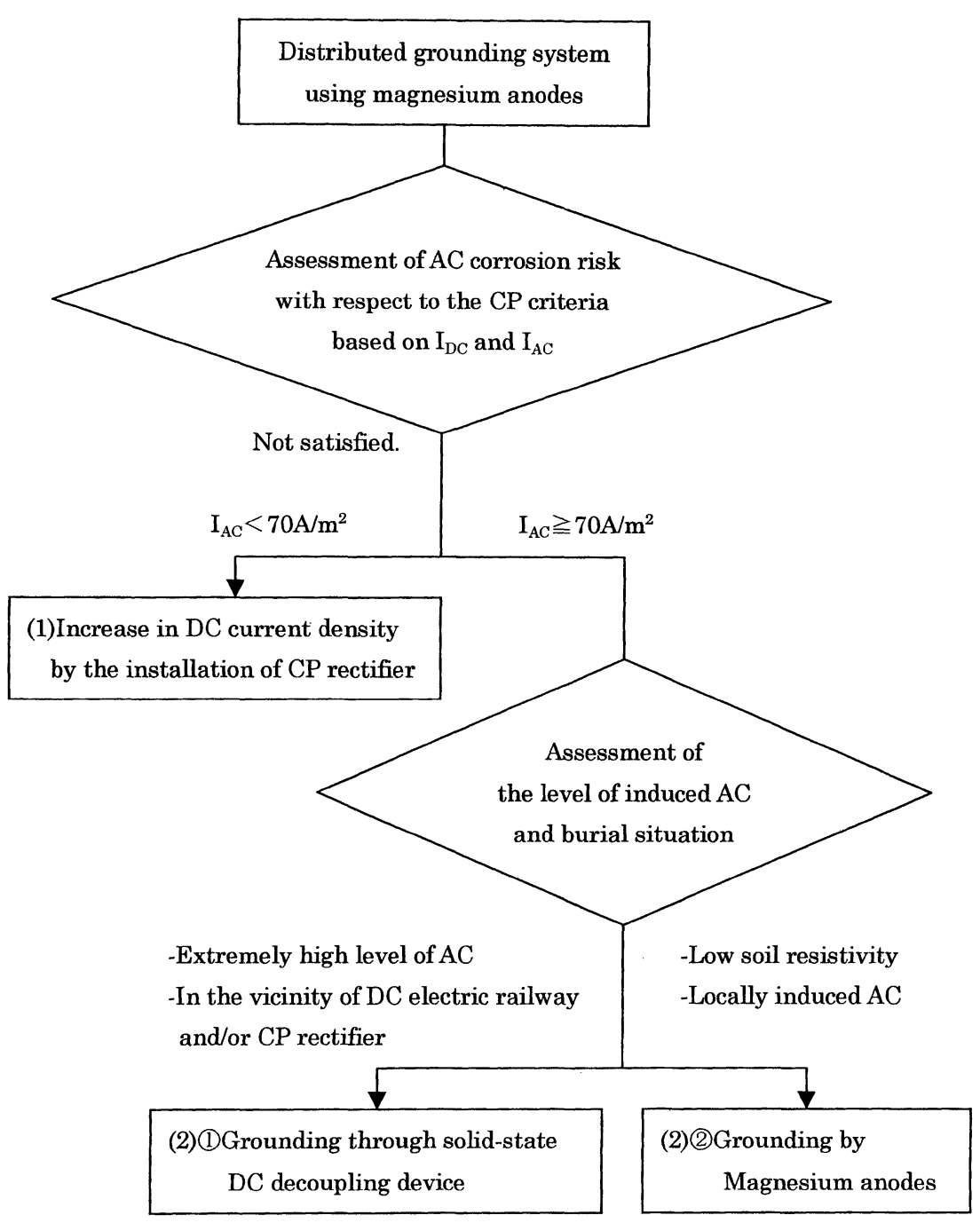

Fig. 2 Methodology for the elimination of AC corrosion risk in the design of CP system.

用する.

次に, プローブ電流密度を計測した結果, パイプライ ンの建設時に接続した $\mathrm{Mg}$ 電極による接地のみでは, 交流誘導の低減が不十分であると判明した地点に対して は, プローブ交流電流密度 $\mathrm{I}_{\mathrm{AC}}$ の大きさに応じて対策を 施す。

(1) $I_{\mathrm{AC}}<70 \mathrm{~A} / \mathrm{m}^{2}$ の時

この場合, 外電によるカソード防食を施して, プロー ブ流入直流電流密度を増加させることにより, 防食が達 成される。

(2) $I_{\mathrm{AC}} \geqq 70 \mathrm{~A} / \mathrm{m}^{2}$ の時

この場合, さらなる低接地化によりプローブ交流電流 密度の低減を図る必要がある。低接地措置の方法とし て, 直流ブロック装置を利用する方法と $\mathrm{Mg}$ 電極を直 接接続する方法の 2 つがあり, 交流誘導レベルや埋設環 境を考慮していずれかの方法を選択する．各方法の特徵 を以下にまとめた。

(1) 直流ブロック装置を利用する方法

これは, 直流ブロック装置 (Solid-state DC Decoupling Device）を介して低接地物とパイプを電 気的に接続することにより，パイプの低接地化を図る ものである．直流ブロック装置は，回路としてコンデ
ンサー, コイル，サイリスタなどから構成され，直流 電鉄からの漏孔電流や外電からの防食電流などの主成 分である直流電流に対しては高インピーダンスで，交 流誘導により発生する交流電流に対しては低インピー ダンスであり, また, 雷電流を大地に逃がす機能も有 する装置である. 特に，以下のようなケースにおいて は，本方法による低接地化が有効である。

・交流誘導のレベルが非常に高いケース

この場合，接地抵抗が $1 \Omega$ 以下といった非常に低い レベルである低接地物を接続する必要がある。しか し，こういった低接地物をパイプと直接接続すると， 防食電流が過大に低接地物に流入して防食効率の低下 を招くため，直流ブロック装置を利用することが有効 である。

・直流電鉄軌条や外電の近傍部で低接地措置が必要とな るケース

この場合，低接地物を直接接続すると，直流電鉄軌 条からの漏れ電流や外電からの迷走電流が低接地物を 介して過度に流入する可能性がある。漏れ電流が流入 した場合は，遠方の塗覆装欠陥で流出する危険性が増 す。また，防食電流が流入した場合は，防食効率の低 下を招く，そこで，直流ブロック装置を利用すること 
により, 漏れ電流や防食電流の流入を防ぎつつ, 交流 誘導の低減が可能となる.

(2) Mg 電極を直接接続する方法

土袞抵抗率が低く, 数本の $\mathrm{Mg}$ 電極のみでも十分 に接地抵抗が低下する場合や, 交流誘導の影響範囲が 局所的であり, 大きな低接地物を必要としない場合に は, $\mathrm{Mg}$ 電極を直接パイプに接続して低接地にするこ とが有効である。

\section{5. 防食設備の配置}

プローブ電流密度を指標としたカソード防食設計を実 施するための準備として, 建設段階よりプローブ, $\mathrm{Mg}$ 電極, 直流ブロック装置の各防食設備を配置した. 以下 にその内容について述べる。

\section{プローブ}

高圧架空送電線近傍, 直流電鉄軌条横断部, 鞘管内な どにおいて，プローブ電流密度を計測するためのプロー ブをパイプ近傍に設置し，これをパイプと接続した。

\section{$\mathbf{M g}$ 電極}

パイプラインは，各工区ごとに分割して建設されてい くため, 建設段階において各管路はそれぞれ電気的に独 立している，そこで，最終的には外電でカソード防食さ れることになるが, 建設期間中の暫定的なカソード防食 を施すため, $\mathrm{Mg}$ 電極を犠牲陽極としてパイプラインに 接続した。 また，本パイプラインは交流誘導の影響を強 く受けており，これら Mg 電極は防食用の犠牲陽極の ほかに，4.に述べたように，交流誘導電圧低減のための 低接地物としても機能している.パイプラインの各工区 ごとに Mg 電極を接続することで, 分散的に接地が確 保できるため，パイプラインの交流誘導電圧を効果的に 低減できる。

犠牲陽極および交流誘導低減用の低接地物として $\mathrm{Mg}$ 電極を選択した理由としては, 土壤中における電位が非 常にマイナス寄りの値であることが挙げられる。すなわ ち，これにより，大きなカソード防食の効果が得られる こと, また, 外電稼動後も外電からの防食電流の流入を 最小限に抑制できるため, 防食効率が低下しないことが 挙げられる。

\section{直流ブロック装置}

本パイプラインの建設途中で交流誘導レベルを調査し た結果, いくつかの地点では Mg 電極による分散接地 のみでは交流誘導電圧が十分低下しないことが明らかに なった。これらの地点では, $\mathrm{Mg}$ 電極の増設では対応し きれないと判断されたため, パイプラインの建設時に使 用した鋼製鞘管など非常に接地抵抗の低い低接地物を, 直流ブロック装置を介してパイプと接続することによ り，交流誘導の低減を図った．直流ブロック装置を介し て接地した箇所は，AラインとBラインで合わせて 2 か所である (Fig. 1 参照).

\section{6. 暫定防食状況評価試験}

\section{1 試験 条 件}

パイプラインの建設終了直後における防食状況を評価 し, 外電の設置位置を決定することを目的として, 暫定

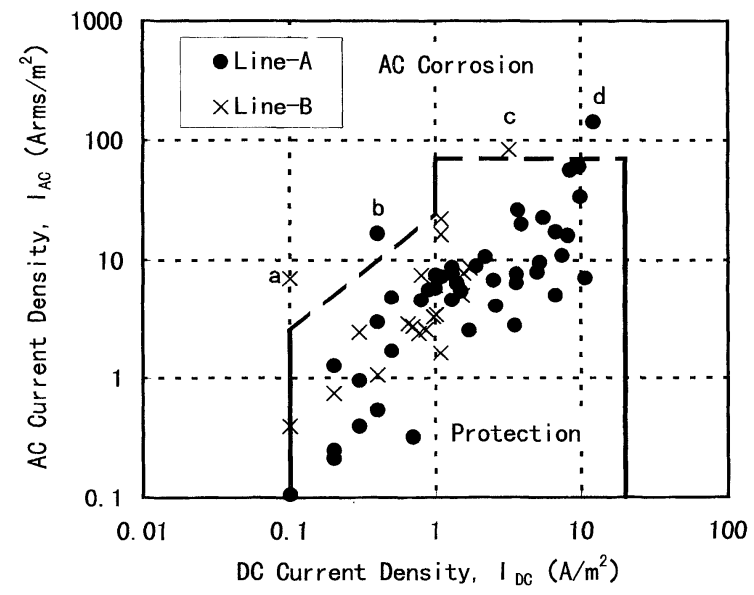

Fig. 3 The results of the CP level evaluation for the pipelines cathodically protected by magnesium anodes with respect to the $\mathrm{CP}$ criteria based on $\mathrm{DC}$ and $\mathrm{AC}$ current densities measured using probes.

防食状況評価試験を行った。本試験では，5.で述べた各 防食設備を配置した状況（暫定防食状況）下で，各 TB においてプローブ電流密度を計測した。なお, 試験は晴 天時において実施した。

\section{2 試 験 結 果}

Fig. 3 に, A ラインおよびBラインの暫定防食状況 下におけるプローブ電流密度の計測結果を示す. $\mathrm{a} \sim \mathrm{d}$ の 4 地点（Fig. 1参照）において, 交流腐食懸念域にあ ることが判明した．このうち， a および bの 2 地点につ いては, 外電を設置して十分な防食電流を流入させるこ とにより，防食が達成される可能性があると考えられ た。これに対し, c および d の 2 地点についてはプロー ブ流入直流電流密度を増加させても防食達成域には入り 得ないことから, 低接地措置を施してプローブ交流電流 密度を低減する必要があると推測された。

また, 複数の地点でプローブ流入直流電流密度が 0.1 $\mathrm{A} / \mathrm{m}^{2}$ もしくはそれに近い值を示していることが明らか になった。これらの地点では, 迷走電流の影響がより強 くなる雨天時などに計測を行うと防食電流不足になるこ とが懸念された。

以上の結果をもとに，Aラインについては 2 基, $\mathrm{B}$ ラインについては 1 基の外電を設置して, それぞれのパ イプライン全体を防食することとした (Fig. 1 参照).

\section{7. 外電設置完工試験}

\section{1 試 験 条 件}

各パイプラインに設置した外電の効果を確認すること を目的として, 外電設置完工試験を行った. この際, $\mathrm{Mg}$ 電極および直流ブロック装置については, 交流誘導 低減対策として必要であることから，すべて接続したま まとした．いずれの外電も，設定電位を $-2 \mathrm{~V}$ として電 位制御で稼動させ, 各 TBにおいてプローブ電流密度 を計測した。 


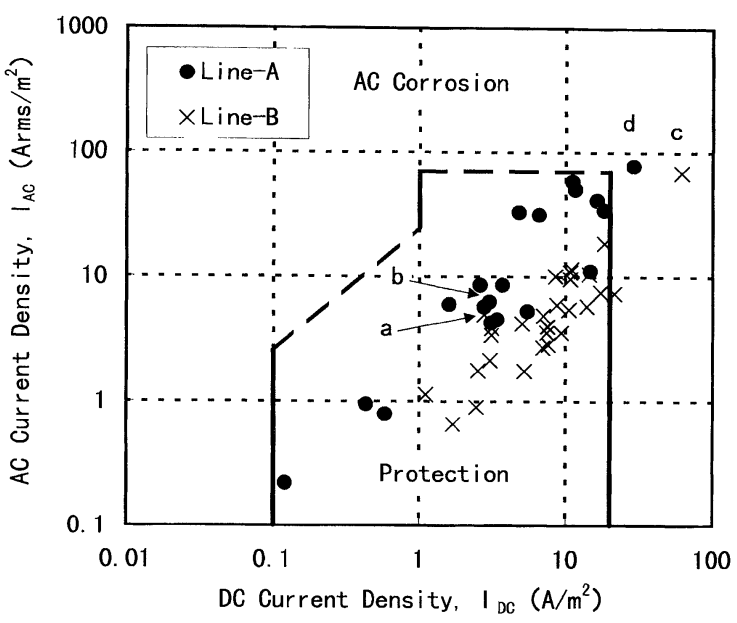

Fig. 4 The results of the CP level evaluation for the pipelines cathodically protected by $\mathrm{CP}$ rectifiers with respect to the $\mathrm{CP}$ criteria based on $\mathrm{DC}$ and $\mathrm{AC}$ current densities measured using probes.

\section{2 試 験 結 果}

Fig. 4 に外電設置完工試験結果を示す. 防食電流の不 足が懸念された地点については, 外電を設置することに より，いずれも十分な防食電流の流入が確認された。ま た，交流腐食の懸念された $\mathrm{a}$ およ゙゙ bの 2 地点について は, プローブ流入直流電流密度の増大により, 防食達成 域に入ることが確認された。 これに対し，プローブ交流 電流密度が $70 \mathrm{Arms} / \mathrm{m}^{2}$ 以上であった $\mathrm{c}$ およ゙ $\mathrm{d} の 2$ 地点については, プローブ流入直流電流密度は増加した ものの, プローブ交流電流密度が低下しないため, 依然 として交流腐食懸念域にあることが明らかになった。

\section{3 交流誘導分布}

本パイプラインにおいて, プローブ交流電流密度が最 大を示した $\mathrm{d}$ 地点（計測地点 TB-7）付近における交流
誘導レベルの分布について検討を行った．検討対象範囲 は, A ラインの路線末端絶縁部〜計測地点 TB-13 であ り, 計測地点は路線末端絶縁部および計測地点 TB4〜 TB-13 の計 11 か所である. A ラインは, 当該範囲の TB-4〜 TB-13 において送電電圧 $66 \mathrm{kV}$, TB-7〜 TB13 において送電電圧 $500 \mathrm{kV}$ の高圧架空送電線とそれぞ れ並行している. TB-7における $66 \mathrm{kV}$ および $500 \mathrm{kV}$ の送電線との離隔距離は，それぞれ $22.7 \mathrm{~m}$ および 48.2 $\mathrm{m}$ である。また，この範囲では，TB-12 を除く 10 か所

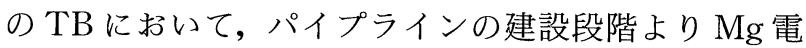
極を 1 ～6 本ずつ接続して低接地化を図っている.

各計測地点におけるプローブ流入直流電流密度 $I_{\mathrm{DC}}$, プローブ交流電流密度 $I_{\mathrm{AC}}$, プローブ $\mathrm{ON}$ 電位 $E_{\mathrm{ON}}$, プ ローブ OFF 電位 $E_{\mathrm{OFF}}$, 交流誘導電圧 $E_{\mathrm{AC}}$ を, 路線末 端絶縁部からの距離を横軸にプロットした結果を Fig. 5 に示す. また，図中には，パイプラインに接続された $\mathrm{Mg}$ 電極の有無についても併せて示した.

$\mathrm{d}$ 地点において，プローブ $\mathrm{ON}$ 電位は $-2.08 \mathrm{~V}$ ，プロ ーブ $\mathrm{OFF}$ 電位は $-1.39 \mathrm{~V}$ と極めて良好な值を示したに もかかわらず，プローブ交流電流密度は $80 \mathrm{Arms} / \mathrm{m}^{2}$ と, 交流腐食の懸念される值を示した. 交流誘導電圧は $\mathrm{d}$ 地点から約 $220 \mathrm{~m}$ 離れた TB-6において最大值 3.3 Vrms を示したが, プローブ交流電流密度は 9 Arms/ $\mathrm{m}^{2}$ であり，防食達成域に入っていた。

このように, 計測位置が $200 \mathrm{~m}$ 程度離れただけでプ ローブ交流電流密度が大きく異なったことは特筆すべき ことである. 本フィールドにおけるデータから判断する 限りにおいては，カソード防食設計を行う際には，200 $\mathrm{m}$ 程度の間隔でプローブ電流密度を計測する必要があ ると言える。すなわち，これより間隔を広げると，プロ 一ブ交流電流密度が基準值を超えて, 交流腐食が発生し 得るような地点を見逃す危険があると言える.

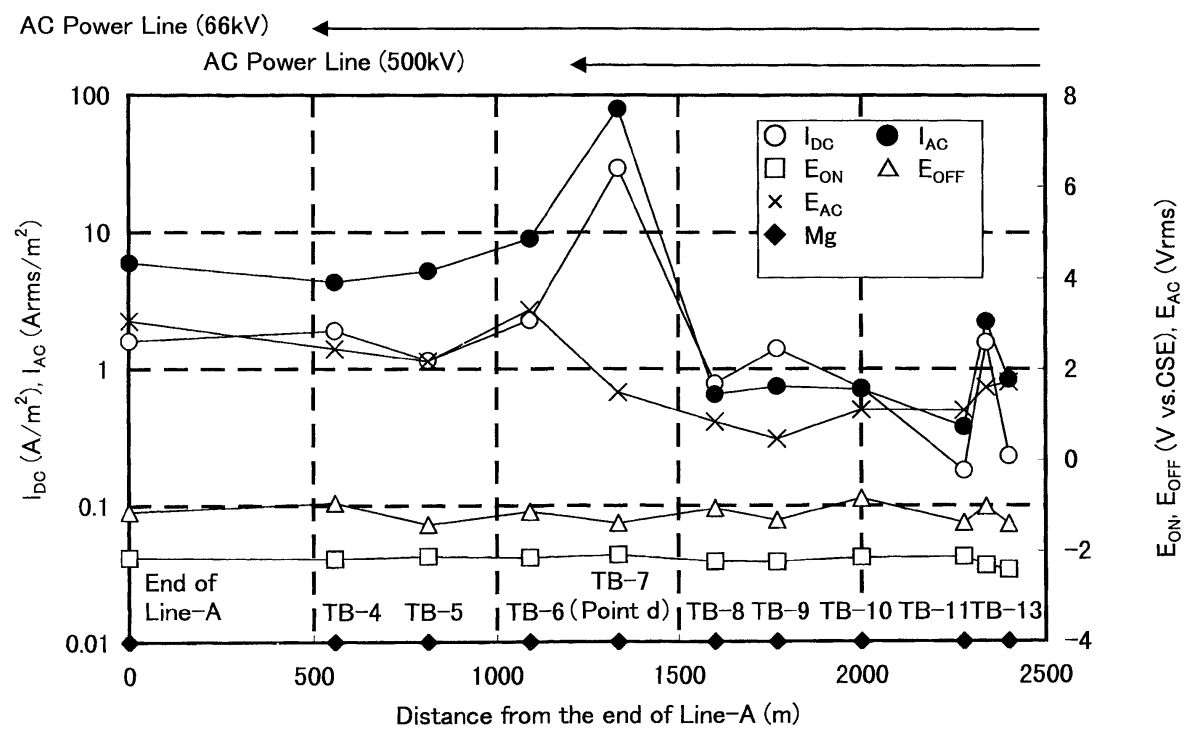

Fig. 5 Distributions of $\mathrm{DC}$ and $\mathrm{AC}$ current densities, probe $\mathrm{ON}$ and probe OFF potentials, $\mathrm{AC}$ induced voltages measured at from TB- 4 to $\mathrm{TB}-13$ where the pipeline is paralleling two overhead high voltage $\mathrm{AC}$ power transmission lines. 


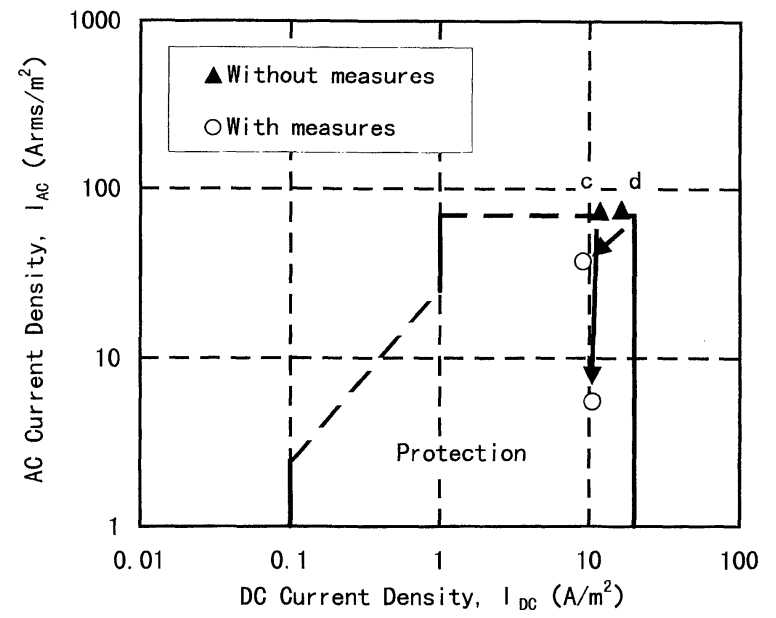

Fig. 6 Assessment of the AC corrosion risk before and after the installation of a solid-state DC decoupling device on the point "c" and magnesium anodes on the point "d".

\section{8． 交流誘導対策評価試験}

\section{1 交流誘導低減措置}

外電設置完工試験の結果, $\mathrm{c}$ 地点および $\mathrm{d}$ 地点におけ る防食達成のためには, 低接地措置を施して交流誘導レ ベルを低下させることが不可欠であることが判明した。 そこで, Fig. 2 に示した交流誘導低減の考え方に従っ て，以下のように低接地措置を施した.

$\mathrm{d}$ 地点については，高圧架空送電線と並行しており， すでに $\mathrm{Mg}$ 電極 1 本が接続されていたが, 4 本追加して 接続することによりさらなる低接地化を図った。

$\mathrm{c}$ 地点については，パイプ近傍に埋設された鋼矢板 を，直流ブロック装置を介してパイプと接続することに より，低接地化を図った。直流ブロック装置を利用した 理由は, $\mathrm{c}$ 地点付近において, パイプラインは直流電鉄 軌道に近接しており, また, 外電が設置されていたた め, 直流電鉄軌道からの漏れ電流や外電からの防食電流 が鋼矢板に流入することを避けつつ交流誘導レベルの低 減を図る必要があったためである。

\section{2 試 験 結 果}

上述の通り，c 地点において直流ブロック装置を介し て鋼矢板と接続する， $\mathrm{d}$ 地点において $\mathrm{Mg}$ 電極を接続す る，という交流誘導対策を実施した後，その効果を評価 するために交流誘導対策評価試験を行った。

Fig. 6 に, $\mathrm{c}$ および $\mathrm{d}$ 地点の交流誘導対策前と対策後 のプローブ電流密度の計測結果を示した。図中に示した ように，低接地措置を施すことで，いずれの地点につい てもプローブ交流電流密度が低減されて，防食達成域に 入ることが確認された。

以上, 各試験を実施し適切にカソード防食設計を進 め, 本パイプライン全線にわたり交流腐食防止, 過防食 防止，鞘管内腐食防止といった観点も含めたカソード防
食が達成された。

$$
\begin{aligned}
& \text { 9. プローブ電流密度を指標とした } \\
& \text { カソード防食設計 }
\end{aligned}
$$

以上のフィールド試験結果より, 交流腐食, 過防食, 鞘管内腐食といったリスクが懸念されるパイプラインに おけるカソード防食設計の手順として以下に示すような フローが考えられる。

(1) 事前調査や建設担当者との協議を行い，パイプライ ンの建設ルートと高圧架空送電線や直流電気鉄道との 位置関係，鞘管が使用されて二重管構造となる区間を 把握する。また，今回報告したパイプラインでは影響 のなかった交流電気鉄道についても，交流腐食を引き 起こし得ることが報告されており ${ }^{3)}$, 交流電気鉄道と の位置関係についても，あらかじめ把握する必要があ る.

(2) これらの情報を元に，プローブ， $\mathrm{Mg}$ 電極，直流ブ ロック装置などの防食設備を適切に配置する。

(3) 建設段階から，プローブ電流密度を計測し，プロー ブ電流密度を指標としたカソード防食管理基準 ${ }^{1)}$ に従 つて評価を行う。この際，基準を満足しない地点に対 しては，外電を仮設置する，交流誘導低減のための低 接地措置を施す，などの適切な対策を施す。

(4) パイプライン建設後に暫定防食状況を評価し，外電 の設置位置や稼動条件を決定する。

(5) 外電設置後，再度防食状況を評価し，基準を満足し ない地点に対しては，外電出力を調整する，交流誘導 低減のための低接地措置を施す，などの適切な対策を 施す。

\section{0. ま と め}

新設されたパイプラインにおいて，交流腐食，過防 食，鞘管内腐食といったリスクが懸念されたため，プロ ーブ電流密度を指標としたカソード防食管理基準に基づ いてカソード防食設計を行った。また，交流誘導低減の ための低接地措置を適正に施した.

同様のリスクが懸念されるパイプラインのカソード防 食設計は，プローブ電流密度を指標として行うことが必 要である.

\section{参 考 文 献}

1）細川裕司，梶山文夫，中村康朗（Y. Hosokawa，F. Ka jiyama and Y. Nakamura)：第 48 回材料と環境討論会講 演集 (Proc. 48 ${ }^{\text {th }}$ Japan Conf. Materials and Environments), p. 545，腐食防食協会 (JSCE) (2001).

2）梶山文夫，中村康朗，細川裕司（F. Kajiyama，Y. Nakamura and Y. Hosokawa) : 第 48 回材料と環境討論会 講演集 (Proc. 48 $8^{\text {th }}$ Japan Conf. Materials and Environments)，p. 553，腐食防食協会（JSCE）（2001）。

3) W. Printz : Proc. UK Corrosion '92, 1 (1992).

(Manuscript received December 3, 2001 ; in final form March 8, 2002) 